\title{
Analysis of the Theory of Acquired Needs from McClelland as a Means of Work Satisfaction
}

\author{
José Abel de Andrade Baptista ${ }^{1}$, Alexandre Formigoni ${ }^{2}$, Sara Almeida da Silva ${ }^{3}$, Caio Flavio Stettiner ${ }^{4}$, Rosana \\ Aparecida Bueno de Novais ${ }^{5}$ \\ ${ }^{I}$ East Zone Technology Faculty Teacher, Paula Souza Center, São Paulo, Brazil \\ ${ }^{2}$ Master's Program Teacher Paula Souza Center, São Paulo, Brazil \\ ${ }^{3}$ Graduated Faculty of Technology of the East Zone, Paula Souza Center, São Paulo, Brazil \\ ${ }^{4}$ SEBRAE Faculty of Technology Coordinator, Paula Souza Center, São Paulo, Brazil \\ ${ }^{5}$ East Zone Technology Faculty Teacher, Paula Souza Center, São Paulo, Brazil \\ Email: abel@fatec.sp.gov.br, alexandre.formigoni@fatec.sp.gov.br,sara.silva27@fatec.sp.gov.br,caio.stettiner@fatec.sp.gov.br, \\ rosana.novais@fatec.sp.gov.br
}

\begin{abstract}
The present work aims to demonstrate the most relevant points in the theory of acquired needs, formulated by the American psychologist David Clarence McClelland in 1961. The theory reports that the individual's success depends on two factors, from the socially acquired experiences to the of life and how these experiences should be treated to understand what needs the individual needs to meet to achieve motivation. From this point, the problem to be studied is intended to understand whether professional success can be measured based on three needs that, when met, would be enough to generate employee satisfaction with their work? The general objective of the research is the analysis of the theory developed by McClelland and how it can be more recently related to the concept of satisfaction in the professional environment. The research method for the proposed theme is a bibliographic search, as it stands out in the use of well-selected and updated information on the subject to be treated, in addition to being the most viable methodology to avoid redundancies in approaching the theme. It was obtained as a result of the analysis that amid so many problems found in managers, according to the point of view of the teams of collaborators, the concern to know the differences and needs of the team has not been a behavior properly adopted by the leadership. Therefore, it was concluded that the theory is useful for the reality of several globalization companies, but the problem lies in the neglect of leadership.
\end{abstract}

Keywords: Motivation, Needs, McClelland.

\section{Introduction}

The way and behavior of human beings in dealing with the demands of work change from person to person, depending on various factors to understand the occurrence of such different reactions from individuals towards the subject of work. Among various ways of approaching this subject, there is motivation and how it can vary among individuals. For Bergamini (2006), motivation can be understood as all the forces or factors that acting in a unified way drive the individual's movement or action to act in different experiences, that is, good or bad.

This study aims to analyze the theory of acquired needs, belonging to the axis called the psychology of differences, which was developed by American psychologist David Clarence McClelland. In general, the theory indicates that the individual's performance is the result of three types of needs (affiliation, achievement and power) that can be learned or socially acquired throughout life experiences.

Each individual has a greater tendency for some specific need among the three, the one that best fits the professional's personality and experiences (Mcclelland, 1972).
The question that mobilizes curiosity about the subject in question is: can people's professional success be measured based on three specific types of needs that, when met, would be enough to generate employee satisfaction with their work? The research hypotheses are: a). Individuals' job satisfaction is temporary, requiring continuous reinforcement; b). Individuals' experiences have a certain variety and randomness of facts or situations, which makes them susceptible to simply achieving adaptation to the environment in which they are inserted; c). The three needs proposed by McClelland have a pre-established order.

The general objective of the research is the analysis of the theory developed by McClelland and how it can be related in a more current way to the concept of satisfaction in the professional environment. As specific objectives, one has: a). to raise relevant data and information about the meaning of McClelland's theory; b). seek results of recent surveys with possible reasons for professional turnover or dissatisfaction in their work; c). relate the dissatisfaction of professionals in their jobs with the perspective reported by McClelland in his theory; d). conclude whether the three 
motivations reported in theory still apply to current contexts in the same way as in the period of its formulation.

As a research justification, one understands that the influence of the psychological issue as a way of understanding the individual in the professional context is of paramount importance. Each form of work motivation must be taken into account and properly analyzed to understand its viability or not for current contexts. Such a statement justifies the choice and development of the following research.

\section{Theoretical Foundation}

Born May 20, 1917, American psychologist David C. McClelland is recognized for his contributions to human motivation. He belonged to a family of scholars, being a brilliant student. At age 16, he was fascinated by German literature, which turned out to be his first college study (Cohen, 1977). However, a short time later one of his professors introduces him to psychology. McClelland begins a new way of studying motivation. His work in this area began in 1947.

Religion was essential to McClelland. His mother was a Presbyterian but his father was a Methodist minister. McClelland studied success in economically well-developed Protestant countries compared to Catholic countries, finding that Protestant parents induced their children to be independent and entrepreneurial, which led them to greater motivations for achievement. For McClelland, all motivation is based on emotion and specifically consists of an expectation of change in the affective condition (Perilla, 1998).

Achieving great notoriety in the field of motivation, McClelland was able to enter Harvard University in 1956, which was where the psychologist was responsible for conducting over a period of 30 years several types of research. At this time, McClelland was already highly recognized for his expertise in the field of human motivation. His methods and theories were already widely applied and standardized in organizational processes.

In his career at Harvard University, McClelland reached the position of chairman of the Department of Social Relations from 1962 to 1967. In general, McClelland's contributions and research did last about five decades of work (Hall, 2007). In addition to the Theory of Acquired Needs and several other outstanding works that the author formulated, McClelland is also widely recognized for his research on the themes of personality and conscience (Perilla, 1998).

Among his contributions to Harvard research, it is development and formulation of a scoring system which was recurrently used for the Thematic Apperception Test (TAT), which was a method to capture needs often used by McClelland, a test type which was planned and designed by
Murray (1938) to help a variety of purposes, for example, possible selection of occupations or research of research partners. According to Hall (2007), the TAT worked as follows, to evaluate some candidates for a job, for example, images are applied in front of the candidate and when telling a story of his imagination about what the image in question represents. Or creating a specific situation for her, the candidate naturally exposed her true motivations for life. TAT is still in operation today.

\subsection{Theory of Acquired Needs}

The theory formulated by McClelland (1972) describes the uniqueness regarding the needs of each individual, showing that the individuality of people makes each person have a different perception of reality and, therefore, need to satisfy different emotional needs (Kolb; Rubin and Mcytire, 1978). McClelland's theory belongs to the axis called the Psychology of Differences or known as the Psychology of Individualities, which deals with the study of human behavior based on the principle that each individual's behavior, no matter how influenced by the environment or various aspects involved, differs in individuality.

The individual aspect is the strategic point of behavior that makes individuals present themselves in a unique way to others, even if they are subtle different, each individual has their unique form of themselves and this branch of psychology is concerned with understanding the consequences of psychological individualities in human beings (Jonassen and Grabowski, 2001). Faced with the psychologist's belief in the connection of the individual emotions with their forms of motivation, in addition to his studies on customs and experiences of economically welldeveloped nations, he was able to formulate his theory of acquired needs. The theory soon became relevant in the understanding of individual motivations for success, through the supply of socially acquired needs during life experiences (Perilla, 1998).

In a way, the theory can also be understood with its connection not only focused on the individual and their behaviors and motives but also acting with the environment and the most viable reactions so that the individual can be accepted before a group and their rules.

In this sense, Gomes (2002) highlights the perspective of the theory of acquired needs, having in one of its characteristics the relation to the individual present in a certain environment having to deal with concepts of learning and problem solving, demonstrating that in certain situations the individual can change their interaction with others, not limited only to their own needs, but to a certain way of surviving the environment.

McClelland recognized that individuals ranked needs differently, identifying three specific needs, namely, need for achievement, need for power and need for affiliation. And while all three needs are present in individuals to some 
degree, the extent to which they are prioritized by individuals differs (Lloyd, 2019). McClelland considers three types of special needs that are learned or acquired in some way through the individual's experiences (Portal Educação, 2013), we will look at each of them below.

\subsubsection{Need for Affiliation}

It is demonstrated by individuals who take the initiative to insert themselves in groups, with the precision of getting to know and interact with their co-workers. According to Jaepil (2006), the individual with this need seeks to convey a good and positive image with whom he relates, in order to build partnerships and feel better positioned or suited to the organization. This need is strongly presented by collaborators with a high capacity to build Networking. This is an interesting need for companies that place a high value on teamwork; Brainstorm process; Organizational climate (Robbins, 2005).

According to McClelland, those with a strong need for affiliation are directed towards friendly relationships and interactions with other people. This individual has a strong desire to be liked, accepted, and held in high regard. These individuals are commonly driven to be team players in a work environment, and like cooperative work situations in which they can engage with many people (Moberg and Leasher, 2011).

\subsubsection{Need for Achievement}

It consists of a type of need that stands out from the rest. Its great difference lies in the fact that it is more linked to the individual's introspective context, being thus parallel to the attitudes of the group to which the individual is inserted.

People with this type of surfaced need tend to seek to improve their performance; gain relevant feedback, that is, from individuals who can criticize the task performed with high attention; feel control over your obligations; gain greater knowledge and involvement with learning, so that it becomes a more agile process; achieve greater challenges and with moderate risks or only essential to the situation (Stoner and Freeman, 1999).

Various empirical studies point out that the need for achievement is the strongest among those in their models. The need for achievement can be defined as a pattern of motivation that reveals self-confidence, great initiative, guided by clearly established goals, assuming moderate responsibilities and risks, and favoring situations that can provide feedback for performance improvement (Sivarajah and Achchuthan, 2013; Ferreira; Loiola and Gondim, 2017).

McClelland (1965), stating that people engaged inactions that achieve results, such as socio-environmental change, are not motivated by money in itself, but use money as a good method for sustaining the level of their achievements.

\subsubsection{Need for Power}

It directs the individual's attention and interest in everything that can give him status and rise over others. This need is specific to individuals who want to take possession of a certain authority; to be seen with value and admiration by others; practice influence so that your opinion is noticed and duly taken into account; inspire all those he works with (Mcclelland, 1972).

Such individuals look at the facts of the organization with a more competitive perspective and see success as a consequence of enjoying a great deal of power in their role.

People with a high need for power are perceived to have an impact on others and are quite overtly looking to build their reputations, position and authority. It has been established that people with a high need for power have a more active, assertive and controlling way in their interactions with others. Power motivation is more about having an impact and wielding persuasive power rather than being more autocratic and authoritative in achieving organizational goals (Jha, 2010).

McClelland and Boyatzis (1982) argued that the need for power is important because it indicates the individual's desires for influence over others. From the point of view of making important decisions, a low need for affiliation is probably better since it is accompanied by a minimal concern about being liked.

\section{Methods}

Before the definition of the theme to be treated, it is extremely important to choose the best method to suit the research in question (Cunha, 2001). The method to be used for the development of the proposed theme is bibliographic research, as it stands out in the investigation of information, reviewing the existing literature to avoid the study becoming redundant (Macedo, 1994).

\section{Results and Discussion}

According to a survey conducted by the Michael Page recruitment consultancy, several professionals pointed out that their greatest work difficulties were due to their bosses or the way the team was managed. According to G1 Economia (2020), the interviewees pointed out as one of the biggest conflicts the lack of recognition and leadership without reference, as if the biggest causes of lack of motivation within organizations were mainly related to the behavior of the leadership, specifically, the lack of understanding towards the most important needs of the team of collaborators.

According to SEBRAE (2019), among the greatest skills expected from a manager, the most necessary to facilitate routine and business development is to provide care and 
attention to people, this skill goes beyond all challenges, it is not enough interacting with a collaborator, you have to understand him. True understanding and attention to the points that motivate the team is the pinnacle of qualitative leadership.

David McClelland studied human behavior in its various aspects, however, his attempt to understand people's motivations, from the perspective that an individual's economic/professional success is a consequence of treating their strengths and needs, was one of his most prominent studies (PERILLA TORO, 1998). According to McClelland (1972), an individual who is not able to expose and achieve an understanding of their true needs in the professional sphere may be destined for financial failure; emotional exhaustion or having their productive capacities compromised.

According to the demands that globalization brought to the business context, the difficulty of understanding the needs of employees became even worse for managers. For Xavier (2006), the obligation to deal with the planning of the entire company and take important decisions in resolving conflicts is no match when it comes to how to know, interact and be attentive to the people who make up the company.

People demonstrate the highest level of complexity in the organization, dealing with just one person is already challenging, dealing with hundreds becomes something of extreme difficulty (Araújo, 2001).

Such findings complete the due reach of the general research objective of this article, because when we consider McClelland's theory with the current scenario, the dimension of the difficulties in achieving real satisfaction in the professional sphere is perceived. Mental health has become the biggest concern of the century and something that has been frequently harmed within organizations (Pimenta, 2018). It is clear that the competitive environment is consequential to a group of individuals who crave growth, but the great difficulty is to prevent this competition from leaving behind the collaborative character of the team and starting to show itself as a conflict of interest and lack of complicity with the friends.

Despite the conflicts, as a proposal to prove the possibility that there is a sequence of steps that the employee must follow to remain in the organization, an interview by UOL (2014) collected some tips, to demonstrate how recurrent that certain attitudes lead a person to gain more respect and prestige among colleagues and, therefore, adaptation to the work environment through this sequence of actions is possible.

However, adequacy is not the same as satisfaction. The adaptation to the environment is about survival, of controlling or trying to be less controllable, and satisfaction is better aimed at the affective issue, the individual's happiness with a certain momentary context, that is, temporary (Fraser, 1996). Which proves the reason for hypothesis A.
As for hypothesis B, it is understood that the experiences of individuals have enough randomness to form the individual's wills, goals and needs and make them try to feel satisfied in an environment, but such experiences can also lead the individual to choose that adequacy is more viable than making greater efforts available to achieve a change in the affective condition (Exame, 2014). Therefore, it appears that hypothesis B is true because the most common attitude among individuals, not only at work, but also in other environments, is adaptability.

At the beginning of this article, it was thought about the possibility that the theory of acquired needs has a strong influence of the Behaviorist approach, which relies on the control of the environment over the individual, shaping their experiences, learnings and all their way of acting with others. people, requiring adaptation (STAATS, 1980), and that this influence should also be associated with the possibility of there being a cycle for the individual to remain satisfied in the environment. Thinking this way, it would be likely that the acquired needs described by McClelland had a predetermined order, which ordered the needs for the individual to begin to belong or feel part of the company, which would be, in that same fixed order: Need for Affiliation, Achievement, and Power.

However, during the research, a major obstacle was noted for this hypothesis to be confirmed as true. Although the psychology of differences approach, to which the theory of acquired needs belongs, also seeks to understand the individual's behavior towards the experiences to which he is exposed, it differs from Behaviorism in a very important point, as it understands that each person has individuality as a primordial characteristic of behavior (Jonassen and Grabowski, 2001).

Therefore, Behaviorism would not be the best comparative approach for the theory of acquired needs, as it takes into account that the environment can be worthy of control and reinforcement of people's attitudes to achieve a goal, that is, manageable, without taking into account the individuality of each being, but rather their instincts and general needs, situated in every human being (Staats, 1980). Which rules out hypothesis $\mathrm{C}$.

\section{Conclusion}

Despite its apparent complexity, motivation is something worthy of strong investment, effort and monitoring in companies, as a good part of business conflicts can be resolved through motivation and its result in employees, Levy-Leboyer (1994, 150) states: Motivation is neither an individual quality nor a feature of work: there are no individuals who are always motivated or equally motivating tasks for everyone. Motivation is much more than a static process. It is a process that is at the same time a function of individuals and the specific activities that they develop. This 
is why the strength, direction and very existence of motivation will be closely linked to the personal way in which each person perceives, understands and assesses their situation at work and certainly not to the perception of those outside it such as technocrats, administrators and psychologists. As a general research objective, we analyze the theory developed by McClelland and how it can be related in a more current way to the concept of satisfaction in the professional environment.

To which the theory proved to be useful and applicable to the current context of companies in different industries, being a powerful tool for analyzing the needs of the team, for its easy understanding and good probability to achieve a good relationship with the team of employees.

However, due to the reports of several employees in satisfaction surveys in the professional sphere, which were carried out recently, it is understood that despite the existence of several tools and theories to support themselves when trying to understand employees, managers and leaders need to greater interest and participation in improving the relationship with the team. Given the findings of the hypotheses, we have:

a) The satisfaction of individuals with work is temporary, requiring continuous reinforcement - True;

b) The experiences of individuals have a certain variety and randomness of facts or situations, which makes them susceptible to simply achieving adaptation to the environment they are inserted in - True;

c) The three needs proposed by McClelland have a preestablished order - False.

Returning to the question that guided the research and understanding initiative regarding the subject in question, we analyze: people's professional success can be measured based on three specific types of needs that, when met, would be enough to generate employee satisfaction with their work? The answer is yes, as the theory of acquired needs can still be applied efficiently in current contexts, bringing different and useful information about employees. In any case, it is understood that the concern to understand the needs of employees should be duly valued, if not for this attempt, for another that better suits the organization's reality (Fundação, 2017). We can understand that when dealing with the theory of acquired needs, even though it was developed in another economic scenario, before globalization and absent from several other aspects present in the daily life of current companies, it still shows itself as a theory of great opportunity for leaders if they interact in the behavior of the team and use it favorably in the development of projects and in the routine of the company itself.

Finally, as well as many other tools and theories with a high capacity to make a difference in a team, if properly used, McClelland's theory of acquired needs still has other ways to be measured and different contexts to be applied. For that, further explorations about its aspects are needed. McClelland left a special legacy in the area of human behavior and his techniques and methods are still used today, although with some improvements. Therefore, it was concluded that, given the results presented in the article in question, McClelland's theory can and should be highlighted more often according to the current socio-economic reality. for greater opportunities to use it.

\section{References}

Araújo, L. C. G. de. (2001) 'Organização, Sistemas e Métodos e as Modernas Ferramentas de Gestão Organizacional' São Paulo, Atlas.

Bergamini, C. W. (2006) 'Motivação nas Organizações' São Paulo, Atlas.

Cohen, D. (1977) ‘Los psicólogos hablan de psicología’ Madrid, Editorial Cátedra.

Cunha, Murilo Bastos (2001) 'Para saber mais: fontes de informação em ciência e tecnologia' Brasília, Briquet de Lemos/Livros.

Exame. (2014) ' 10 passos para se adaptar rapidamente a qualquer trabalho' Available from: https://exame.com/carreira/os-dez-mandamentos-para-seadaptar-a-qualquer-trabalho/. Access in: 01 de Ago. de 2021.

Ferreira, A. S. M.; Loiola, E.; Gondim, S. M. G. (2017) 'Motivations, business planning, and risk management: entrepreneur shipamong university students' RAI Revista de Administração e Inovação 14, 140-150.

Fraser, T. M. (1996) 'Work, fatigue, and ergonomics. In: Introduction to industrial ergonomics: a textbook for students and managers (online)' Toronto: Wall and Emer-son. Available from: http://www.wallbooks.com/source/fraser.htm. Access in: 10 de Jun. de 2021.

Fundação, da S. M. (2017) 'Como apoiar saúde mental no trabalho’ Available from: https://www.mentalhealth.org.uk/ publications/how-support-mental-health-work. Access in: $10 \mathrm{de}$ Nov. de 2020.

G1 Economia. (2020) '8 em cada 10 profissionais pedem demissão por causa de seus chefes' Available from: https://g1.globo.com/economia/concursos-e-emprego/noticia/ 2019/11/22/8-em-cada-10-profissionais-pedem-demissao-porcausa-do-chefe-veja-os-motivos.ghtml. Access in: 11 de Fev. de 2021.

Gomes, F. R. (2002) 'Clima organizacional: um estudo em uma empresa de telecomunicações' Revista de Administração de Empresas, v.42, n.2, Abr./Jun, p.95-103.

Hall, W. J. (2007) 'David McClelland' Available from:: https://psychology.fas.harvard.edu/people/david-mcclelland. 
Vol.3, Issue2, pp.54-59, 2021

Access in: 10 de Nov. de 2020.

JaepiL, C. (2006) 'A Motivational Theory of Charismatic Leadership: Envisioning, Empathy and Empowerment' Journal of Leadership \& Organizational Studies, v.13, n.1, p.24.

Jha, S. (2010) 'Need for Growth, Achievement, Power and Affiliation: Determinants of Psychological Empowerment' Global Business Review, 11: 379.

Jonassen, D. H.; Grabowski, B. L. (2001) 'Handbook of individual differences: learning \& instruction' Lawrence Erlbaum Associates, Inc., Publishers, Hillsdale, New Jersey.

Kolb, D. A; Rubin, I. R; Mcintyre, J. M. (1978) 'Psicologia organizacional: uma abordagem vivencial' São Paulo, Atlas.

Levy-Leboyer, C. (1994) 'A crise das motivações' São Paulo, Atlas.

Lloyd, W. (2019) 'Entrepreneurial motivation: the impact of cultural capital on the 'who' is motivated', Int. J. Business and Globalisation, Vol. 23, No. 1, pp.139-152.

Macedo, N. D. de. (1994) 'Iniciação à pesquisa bibliográfica: guia do estudante para a fundamentação do trabalho de pesquisa'. São Paulo, Edições Loyola.

McClelland, D. C. (1965) 'Toward a theory of motive acquisition' American Psychologist, 20, 321-333.

Mcclelland, D. C. (1972) 'A Sociedade Competitiva realização e progresso social' Rio de Janeiro, Expressão e Cultura.

McClelland, D. C.; Boyatzis, R. E. (1982) 'Leadership motive pattern and long-term success in management' Journal of Applied Psychology, 67(6): 737.

Moberg, C. R.; Leasher, M. (2011) 'Examining the differences in salesperson motivation among different cultures' American Journal of Business, Vol. 26 Iss 2 pp. 145 - 160.

Murray, H. A. (1938) 'Explorations in personality' New York, Oxford University Press.

Robbins, S. P. (2005) 'Comportamento Organizacional' São
Paulo, Pearson Prentice Hall.

Perilla Toro, L. E. (1998) 'David C. McClelland (1917 -1998)' Revista Latinoamericana de Psicología, V. 30, n.3, pp.529-532, 1998.

Pimenta, T. (2018) 'Saúde mental no ambiente de trabalho' Available from: https://www.vittude.com/empresas/saudemental-no-ambiente-de-trabalho. Access in: 10 de Jun. de 2021.

Portal Educação. (2013) 'A teoria McClelland' Available from: https://www.portaleducacao.com.br/conteudo/artigos/enfermag em/a-teoria-mcclelland/35557. Access in: 05 de Jul. de 2021.

SEBRAE. (2019) 'O sucesso do negócio depende de uma boa gestão de equipe' Available from: https://www.sebrae.com.br/sites/PortalSebrae/artigos/boagestao-de-pessoas-resulta-em-sucesso-nonegocio,4423438af1c92410VgnVCM100000b272010aRCRD. Access in: 20 de Mar. de 2021.

Staats, A. W. (1980) 'Behaviorismo social: uma ciência do homem com liberdade e dignidade' Arquivos brasileiros de psicologia 32(4): 97-116.

Stoner, J. A. F; Freeman, R. E. (1999) ‘Administração’ Rio de Janeiro, LTC, 1999.

Sivarajah, K.; Achchuthan, S. (2013) 'Entrepreneurial intention amongunder graduates: Review of literature'. European Journal of Business andManagement, 5(5), 172-186.

UOL. (2014) 'Como sobreviver e se adaptar a mudanças no seu trabalho' Available from: https://economia.uol.com.br/empregos-ecarreiras/noticias/redacao/2014/06/05/saiba-como-sobrevivere-se-adaptar-a-mudancas-no-seu-trabalho.htm. Access in: 15 de Abr. de 2021.

Xavier, R. de A. P. (2006) 'Gestão de pessoas na prática: Os desafios e as soluções' São Paulo, Editora Gente. 